\title{
JAPANESE PATHWAYS TO PEACEBUILDING: FROM HISTORICAL LEGACIES TO CONTEMPORARY PRACTICES
}

\author{
Kazushige Kobayashi* \\ Graduate Institute of International and Development Studies, Geneva ${ }^{* *}$
}

DOI: $10.20542 / 2307-1494-2020-1-9-25$

\begin{abstract}
Existing literature on peacebuilding arguably pays too much attention to host societies and not enough to the peacebuilders themselves. This article shows that, in many ways, Japan"s contemporary approach to peacebuilding is the outward projection of its own postwar reconstruction experience. That experience constitutes a case of (re)building a postwar society by a transitional authority maintained by foreign intervention. In this process, the United States earned lasting and wide-ranging respect from many postwar Japanese citizens. It acted as a competent autocrat who effectively controlled information, imposed a strictly hierarchical order, tamed civil society, contained the seeds of postwar social disturbances, and paved the way for Japan"s miraculous postwar growth. Within this framework, Japan successfully reconstructed the war-torn nation without local ownership, widespread democratic participation, or civil society involvement. This postwar experience profoundly informs Japan"s peacebuilding policy that emphasizes the norms of state sovereignty, effective hierarchical governance, and socio-economic development as key legitimizing principles. A historicallygrounded approach to the foundation of Japanese peacebuilding policy highlights the need to reconsider the taken-for-granted assumptions about the homogeneity of the liberal peace. More generally, the much-needed debate about the role, vision, and agency of non-Western peacebuilders offers a promising avenue for future research.
\end{abstract}

Keywords Japan, postwar reconstruction, liberal peace, peacebuilding, democratization, development cooperation, foreign occupation, non-Western powers, historical legacies

\footnotetext{
Kazushige Kobayashi (Japan) is Postdoctoral Researcher at the Centre on Conflict, Development and Peacebuilding, Graduate Institute of International and Development Studies, Geneva (Switzerland).

Казушиге Кобаяши (Япония) - исследователь Цента по конфликтам, развитию и миростроительству Института международных исследований и развития, Женева (Швейцария).

** This article has been prepared as a part of a collaborative international research project "Coherence or Contestation: Chinese, Japanese and Russian Approaches to The Transformation of Peacebuilding Practices" hosted by the Centre on Conflict, Development and Peacebuilding of the Graduate Institute of International and Development Studies in Geneva, Switzerland. The three-year project, funded by the Swiss National Science Foundation and expected to be completed in September 2021, has involved desk research, a review of key policy documents (of the UN and three target countries), and nearly 100 semi-structured interviews with peacebuilding officials, academics, and civil society representatives in Geneva, New York, Beijing, Shanghai, Tokyo, Hiroshima, and Moscow. The perspectives and arguments provided by this article are broadly grounded in the insights gained through this extensive field research.

The author would like to thank Keith Krause, Oliver Jütersonke, Xinyu Yuan, the Journal's editors and reviewer for their constructive comments. The author retains sole responsibility for any errors or omissions.
} 
$\begin{array}{ll}\text { Название } & \text { Подходы Японии к восстановлению мира: от исторического опыта } \\ \text { статьи } & \text { к современным практикам }\end{array}$

Аннотация Существующая литература по миростроительству уделяет основное внимание обществам, принимающим помощь по восстановлению мира, и недостаточно фокусируется на тех, кто эту помощь предоставляет. В статье показано, что современные подходы Японии к миростроительству во многом являются проекцией вовне ее собственного опыта послевоенного восстановления. Этот опыт является примером восстановления послевоенного общества переходными властями, сформированными в условиях иностранной интервенции. В ходе этого процесса США приобрели стойкое уважение со стороны значительной части японских граждан тем, что действовали как компетентная автократия, эффективно контролировавшая информационные потоки, установившая иерархическую властную вертикаль, державшая под контролем гражданское общество, гасившая источники социального недовольства и проложившая путь к послевоенному японскому экономическому чуду. В рамках этой модели Японии удалось восстановить страну и общество в отсутствие «ответственности на местах», широкого демократического участия, сопричастности населения и вовлеченности гражданского общества. Этот послевоенный опыт оказывает значительное влияние на современную политику Японии в области миростроительства за рубежом, которая делает упор на таких основополагающих принципах как соблюдение норм государственного суверенитета, эффективная вертикаль власти и социально-экономическое развитие. Подход к изучению японской модели миростроительства, основанный на анализе ее исторической подоплеки, диктует пересмотр привычного тезиса о гомогенности либерального мира. В целом, давно назревшая дискуссия о роли, видении и акторах незападных направлений и моделей международного миростроительства указывает на перспективное направление дальнейших исследований в этой сфрере.

Ключевые слова
Япония, послевоенное восстановление, либеральный мир, миростроительство, демократизация, сотрудничество в области развития, иностранная оккупация, незападные державы, исторический опыт

\section{Introduction}

Although contemporary literature on peacebuilding predominantly revolves around Western actors, Japan - which retains an ambiguous identity in-between the West and the non-West - has played an increasingly important role in global peace operations. ${ }^{1}$ In 1989, Japan"s annual official development assistance (ODA) exceeded that of the United States and Japan became the world"s largest ODA contributor. Despite the prolonged economic stagnation after 1991, Japan largely retained the position of the largest ODA contributor until the late 1990s. In 2017, Japan"s total ODA amounted to 11.46 bln USD, making it the fifth largest donor in the world. ${ }^{2}$

Despite its status as an "aid great power", ${ }^{3}$ Japanese assistance for peacebuilding is a relatively new endeavor and is still evolving. Assistance for peacebuilding first emerged as a policy priority in the 2003 revision of the ODA Charter, preceded by the release of a 2002 policy report by the Advisory Group for International Peace Cooperation (AGIPC), or Kokusaiheiwakyouryoku Kondankai. ${ }^{4}$ The final report of the AGIPC proposed a "New Concept of International Peace Cooperation" (atarashii 
kokusaiheiwa kyouryoku) and defined the peacebuilding formula as the consolidation of peace (heiwa no teichaku) plus statebuilding (kunidukuri). ${ }^{5}$ The emphasis on peacebuilding assistance as a major component of Japanese development cooperation also made it into the latest 2015 Development Cooperation Charter.

In recent years, scholars have begun to pay closer attention to non-Western engagement in peace operations, ${ }^{6}$ and Japan"s engagement in peacebuilding has received increasing - although probably still insufficient - scrutiny. In Japanese peacebuilding scholarship, researchers actively debate what Japan"s contributions to international peace are, how Japan has engaged in peacebuilding activities, and how Japan"s approach to peacebuilding converges to and/or differs from liberal Western mainstream. ${ }^{7}$ The growing body of Japanese peacebuilding literature, mostly written in Japanese, has shown that the Japanese approach emphasizes basic human needs (BHNs), socio-economic/infrastructural development, national ownership, state sovereignty, and peace through development. ${ }^{8}$ In recent years, the Japanese Ministry of Foreign Affairs (MOFA) and the Japan International Cooperation Agency (JICA) have proclaimed "building a resilient state" (hereafter shorthanded as "resilient statebuilding") as its official peacebuilding doctrine and pursues greater engagement with conflictaffected states. $^{9}$

Although existing research clarifies Japanese visions, norms, and principles of peacebuilding and their ideational and material underpinnings, there remains a critical gap with regard to where these visions, norms, and principles come from in the first place. Indeed, a general weakness of contemporary norm research in International Relations (IR) scholarship is that researchers tend to assume norms as pre-given, rather than critically investigating broader politico-historical currents that have shaped these norms over time. Put differently, norms are not only ideational factors enabling and/or constraining development cooperation policy, but also the accumulation of historical knowledge and processes. In this vein, Hideaki Shinoda, professor at Tokyo University of Foreign Studies and director of Hiroshima Peacebuilders Center, insightfully argues that Japan"s contemporary approach to peacebuilding has been shaped by its own experiences of building peace after 1868 (the civil war and the Meiji Restoration) and 1945 (the defeat in the Second World War and the subsequent American occupation). Indeed, this is in line with John Ruggie"s argument that states often engage in outward projection of their own domestic experiences. ${ }^{10}$ While Shinoda cautioned that Japan"s postwar experiences might not be directly transferable to other post-conflict states, he nonetheless emphasized that Japan"s postwar reconstruction was a case of (re)building a peaceful postwar society by a transitional authority maintained by foreign intervention. Indeed, under American leadership, the General Headquarters of the Supreme Commander for the Allied Powers (GHQ) implemented a series of disarmament, demobilization, and reintegration (DDR) and security sector reform (SSR) programs, ${ }^{11}$ although, of course, these programs were not called DDR and SSR in those days.

Japan routinely distances itself from the standard practices of the liberal peace paradigm. The 2009 JICA report on peacebuilding even warned that rapid democratization in post-conflict countries can amplify local instability. ${ }^{12}$ Despite its membership in Organization for Economic Cooperation and Development (OECD) and its close alignment with the West on most UN resolutions, why does Japan"s approach to peacebuilding prioritize the norms of state sovereignty, effective hierarchical governance, and socio-economic development? Despite its status as a major international donor, why has Japan refrained from advancing active normative leadership in peacebuilding? In asking these important questions, this article does not advance a systematic causal 
analysis; instead, it presents a historical analysis elucidating broader social contexts that have shaped Japan"s overall approach to peacebuilding.

The article shows that Japan"s contemporary approach to peacebuilding practice is the outward projection of its own postwar reconstruction experience, which itself constitutes a case of (re)building a peaceful postwar society by a transitional authority maintained by foreign interventions. In this vein, the author concurs with Shinoda that a fuller understanding of Japan"s contemporary international engagement needs to be grounded in its own postwar reconstruction. Yet this article also takes this argument a step further and shows that Japan"s ambiguous normative stance towards the liberal peace paradigm is deeply rooted in its paradoxical postwar experiences, in which liberal democratic values were successfully imposed upon postwar Japan by illiberal and authoritarian means.

The article has four sections. Following the introduction, section II briefly reviews Japan"s postwar reconstruction. Grounded in these insights, section III connects the legacies of the past to the practices of the present and explains why Japan retains an ambiguous stance towards the liberal peace, as well as why it has refrained from active normative leadership in peacebuilding. The final section concludes with suggestions for further research. ${ }^{13}$

\section{The legacy of authoritarian "liberal” peace in postwar Japan}

For many democratization and peacebuilding scholars, Japan"s post-war transformation seemingly constitutes a shining example of the postwar liberal peace. ${ }^{14}$ Henry Kissinger posits that the United States "sought victory not in domination but in sharing the fruits of liberty" ${ }^{15}$ and successfully transformed a war-prone empire into a world-class economic powerhouse. The simplistic narrative of Japan"s linear transformation from war-torn authoritarian empire to a U.S.-allied liberal democracy, however, obscures the complex processes and contradictions of this occupied "liberalization" where liberal reforms - which have undoubtedly benefitted the majority of Japanese citizens - were chiefly advanced through authoritarian occupation, autocratic societal control, and illiberal, quasi-one-party system. Hence, in light of Japan"s lived experiences of postwar reconstruction, the binary of liberal/illiberal and democratic/undemocratic does not make much sense.

After 1945, General MacArthur ruled with his "authoritarian personality" like an autocrat and symbolized an extremely personified occupation regime where all reforms were implemented in his name. ${ }^{16}$ As Shinoda pointed out, GHQ skillfully advanced information campaigns depicting Emperor Hirohito as a fallen democrat who had been abused by corrupt imperial elites. This narrative quickly gained popularity among the Japanese citizens, who eventually came to see America as the defender of the imperial realm. ${ }^{17}$ General MacArthur strategically mobilized the rehabilitated moral authority of the Emperor as a legitimizing device to consolidate his occupation regime. As Seymour Lipset posited, "It is important to note that the great Japanese post-war reforms (e. g., land reform, democratization, demilitarization, and the elimination of the peerage) were legitimated by the same mechanism as in the Meiji Restoration, the Emperor"s approval... General MacArthur played out the classic role of a controlling Shogun standing behind the Emperor, but by doing so he helped preserve much of the older traditions." ${ }^{18}$ Although Joji Matsumoto, Japanese legal scholar and the minister in charge of postwar constitutional reform under the Cabinet of Baron Shidehara, was the first to draft the new postwar constitution, this draft was swiftly rejected by GHQ. General MacArthur then single-handedly ordered a selected number of American occupation 
officials to draft the new Japanese Constitution. These U.S. officials had received American legal training, but had no knowledge of Japanese language, culture, or tradition. Despite this, they successfully, though hastily, drafted the new Japanese Constitution in just eight days. ${ }^{19}$ Indeed, in 2016, former U.S. Vice-President Joe Biden proudly proclaimed that "...we [Americans] wrote Japan"s Constitution." 20

What it important to stress here is not only the fact that Japan"s new constitution was hierarchically imposed by foreign occupation forces ("forced to be free," in the words of John D. Montgomery), ${ }^{21}$ but, more importantly, that it has worked extremely well for Japan, despite the lack of local ownership, democratic participation, and civil society involvement. While Japanese scholars and policymakers continue to debate how Japan"s postwar experience may be useful for other war-torn societies, Japanese policymakers have a lived experience that it is certainly feasible - if not entirely desirable - to reconstruct a vibrant postwar nation without wide-ranging civic participation. Indeed, what makes Japan"s miraculous postwar recovery notable is the absence of a strong civil society and open political system - the components often proclaimed to constitute the core of mainstream liberal peacebuilding (see below).

In particular, the total information control initially instituted by the occupation regime appears to have contributed to the pacification of Japan"s postwar society. Based on the empirical insights gained from the conflicts in the Balkans and Rwanda, Jack Snyder and Karen Ballentine concluded that a stricter control of media might be necessary to institute stability in postwar societies. ${ }^{22}$ This, indeed, has been the experience of postwar Japan. After 1945, the GHQ"s Civil Information and Educational Section issued strict presscodes prohibiting the publication of materials expressing independent opinions uncensored by the occupation authority. Taketoshi Yamamoto systematically reviewed hundreds of original declassified materials in the U.S. archives and concluded that the U.S. occupation authorities mobilized more than 8000 surveillance officers (many of them locally-hired Japanese citizens paid to remain loyal to the United States) to exercise total control over all aspects of postwar Japanese life. ${ }^{23}$ All broadcasts and newspapers were fully controlled by designated American editors, while the total surveillance system also censored private letters, phone calls, telegrams, movies, photos, poems, theaters, jokes, and all other aspects of civic life. Any criticism of the U.S. government, crimes committed by American officials and soldiers (e.g. mass rapes), atomic massacres of Hiroshima and Nagasaki, and widespread kleptocracy (often involving Americans) was absolutely prohibited. Those who refused to comply with the censorship were promptly dismissed from work and/or were hastily put on trial at the military court and sentenced to forced labor (some of them were mobilized to construct American military bases in Japan). ${ }^{24}$ It is true that the occupation forces implemented liberal reforms such as the dismantlement of the military and oligarchy and Western-style progressive public education, ${ }^{25}$ but these reforms were nonetheless implemented in a strictly autocratic way, without meaningful participation of ordinary local citizens.

This quasi-totalitarian model of a fully controlled postwar society was eventually relaxed in the late 1940s. Japan"s sovereignty was restored with the signing of the 1951 San Francisco Peace Treaty. What emerged after the occupation, however, was a similarly hierarchical political system characterized by the hegemony of the Liberal Democratic Party (LDP), the so-called 1955 Regime. The regime was consolidated by prime minister Shigeru Yoshida (grandfather of current vice prime minister Taro Aso) and Prime Minister Nobusuke Kishi (grandfather of current prime minister Shinzo Abe). Under the 1955 Regime, perpetual electoral manipulations functioned as a basis for regime endurance. ${ }^{26}$ As a consequence, regime legitimization in postwar Japan"s "developmental state" ${ }^{27}$ occurred mostly through the protection of national traditions, the 
maintenance of domestic stability, and the sustainment of major economic growth. In 1954, Japan"s GNP was just about 190 USD, slightly higher than that of the Philippines (150 USD), but significantly lower than that of Malaya (310 USD). ${ }^{28}$ But the U.S.-backed developmentalist governance model worked so well that, only fourteen years later, in 1968, Japan rose to the position of the second largest world economy. Shinoda compares this LDP model to those of other Asian nations who sought a similarly developmentalist path to peace:

"The strategy is not to seek a political compromise with the opposition through peace negotiations, but to control popular dissatisfaction by distributing economic dividends to ordinary citizens, while at the same time maintaining territorial integrity by adopting a politically and militarily authoritarian model - this is the strategy adopted by every Asian nation that achieved remarkable economic development, most notably Japan, led by the LDP's long-term non-coalition government, but also South Korea, Taiwan, China, Indonesia, Malaysia, Singapore, and Thailand". ${ }^{29}$

As such, the practical experience of building a peaceful and prosperous nation after the war largely informs Japan"s contemporary approach to peacebuilding. In this vein, a Japanese academic who has worked for and with various Japanese government-funded peacebuilding projects emphasized the primacy of BHNs: citizens who struggle in perpetual poverty have no time or space to engage in peace and politics. ${ }^{30}$

Succeeding MacArthur"s occupation regime, postwar Japanese governments have suppressed independent civil society not despite Japan"s alignment with the West, but because of it. In fact, Japan witnessed a meteoric rise of civic activism in the 1950s and 1960s, but a large portion of postwar Japanese civil society advanced causes of democracy, human rights, women empowerment, and peaceful international relations against American/Western dominance in world affairs. When the Japanese government decided to renew the Japanese-American Security Treaty in 1960 without consulting the broader society, nearly half a million protesters, mainly led by student movements and youth activists, flocked to the Diet (Japan"s parliament). In Okinawa, where the majority of U.S. military bases in Japan is concentrated, women and peace activists mobilized tens of thousands of concerned citizens to fight for equality, dignity, and human rights against rapes and murders committed by American soldiers, most of which have not been punished by free and fair judicial processes. ${ }^{31}$ Indeed, Japan"s main venue of peace research - the Peace Studies Association of Japan - has for long advanced leftist/liberal research agendas against the U.S.-backed conservative governments in Tokyo. Even today, many Japanese civic and academic groups that engage in peace research and activism proclaim to defend universal liberal values against illiberal and unaccountable American/Western dominance in the world. ${ }^{32}$

For these historical reasons, Japan"s present government generally remains skeptical of independent civil society actors, as they are often seen as an obstacle to a stronger partnership with the United States. In peacebuilding, Japan prefers to work with non-political service-provider NGOs and government-coordinated civic platforms such as the Japan Platform that functions as an intermediary interface for promoting Japanese humanitarian aid. In 2002, when the Japanese government hosted the Afghan Reconstruction Conference in Tokyo, the Japan Platform and the Peace Winds Japan (an independent Japanese NGO founded by British-educated Ken Onishi) were asked to participate in the conference as representatives of Japanese civil society. Yet when Onishi, at the time also the Executive Coordinator of the Japan Platform, remarked in an open interview that "I do not fully trust our government," he and his colleagues were promptly denied entrance to the conference. The "Asahi Shinbun" daily cited a senior foreign ministry official asserting that "we cannot allow non-cooperative NGOs to attend 
the Conference." This attitude is a reflection of the postwar political regime in which civil society has been primarily seen as a problem to be managed and coopted. A very limited role of the civil society in postwar Japan"s policymaking processes is reflected in the fact that Japan only established its first comprehensive civil society legislation (The Specified Non-Profit Organization Promotion Act) in $1998 .^{33}$

\section{Passive is beautiful?}

Japan"s postwar experience profoundly shaped its identity as a nation which respect to the sovereignty of others. As discussed above, America"s interference into political, constitutional, and judicial affairs in postwar Japan prompted Japanese liberal intellectuals and civil society activists to disparage the "unsovereign" democracy of Japan, in which the will of the American hegemon sat far above the will of the Japanese people. ${ }^{34}$ Even the pro-American Prime Minister Shigeru Yoshida who had studied in the U.K. and subsequently served as a postwar Prime Minister under American occupation decried that the American approach to postwar governance was "obsessed with ideals and... prone to disrespect others" feelings. They first come up with a perfect plan, and once they decide that this is a good plan, they forcefully impose it upon others. Despite their goodwill, they totally ignore others" feelings and historical traditions". ${ }^{35}$ While American occupation was helpful in spurring Japan"s miraculous postwar recovery, many Japanese officials who lived through the period of foreign-imposed "good governance" experienced a profound sense of helplessness. ${ }^{36}$ In light of this traumatic historical experience, JICA researchers show that Japan"s development cooperation policy has consistently defended the norm of Westphalian sovereignty and non-interference precisely because Japanese policymakers know how it feels to have foreign norms imposed in the name of "democratization." J7 JICA"s 2018 summary of "Japanese-style" legal/governance reform assistance explicitly proclaims that "the external imposition of an „advanced" legal system on recipient nations can never succeed." ${ }^{38}$

Japan"s postwar state identity as a former aggressor also made it difficult for the Japanese officials to pursue activist aid policy. Western scholars and policymakers tend to treat post-1945 Japan as a passive "norm-taker" in the international arena, the one that shied away from value-assertive foreign policy. ${ }^{39}$ This understanding needs to be contextualized further. Japan does not only passively follow the international mainstream, but it has a different worldview on norms and normative foreign policy based on the outward projection of its own domestic experiences. Initially, Japan"s postwar foreign aid began in the 1950s as a tacit compensation for the sufferings that had been inflicted by the Japanese Empire. ${ }^{40}$ Instead of following the OECD aid guidelines, Japan developed an alternative aid model - the so-called "request-based system" that stipulates that donors should provide foreign aid only when it is requested by recipient countries. The request-based policy emphasizes equal partnership between donors and recipients, win-win cooperation for mutual benefits, unconditional respect for the sovereignty of the host state, and national ownership. ${ }^{41}$ Japan"s peacebuilding policy that has been largely defined as development cooperation in fragile and conflict-affected contexts ${ }^{42}$ is driven by the imperatives of the request-based system. Throughout the author"s interviews, senior JICA peacebuilding officials remarked that, while Japan certainly does not deliberately aim to promote autocratic governance, the respect for sovereignty should form the fundamental basis of conflict management and post-conflict reconstruction. ${ }^{43} \mathrm{~A}$ former UN official who has longstanding working relationship with the Japanese government remarked that the majority of Japanese officials are not interested in governance reform agendas and believe that outsiders should not attempt to stir 
domestic political processes. ${ }^{44}$ Within the UN peacebuilding architecture, the UN Peacebuilding Commission (PBC) whose targets are selected on the basis of voluntary applications filed by countries in need themselves is especially congruent with the Japanese approach that emphasizes sovereignty, autonomy, and self-reliance.

The author interviewed 24 Japanese government officials, former UN officials from Japan, Japanese civil society representatives and peacebuilding scholars. All of them without exception confirmed that Japan does not prioritize governance/democracy reforms or political/human rights agendas. Japan"s emphasis on state sovereignty that has been systematically articulated by senior Japanese officials in the interviews conducted entails both negative and positive repercussions. ${ }^{45}$

On the negative side, Japanese peacebuilding assistance (and development cooperation in general) has been internally and externally criticized for propping up seemingly despotic sovereign governments. For instance, Japan is the only OECD Development Cooperation Directorate (DAC) member that has consistently supported Myanmar"s government since the 1990s. ${ }^{46}$ In a similar vein, Ken Inoue, the former Chief Governance Advisor of the UN Integrated Mission in Timor-Leste (UNIMET)"s Democratic Governance Support Unit, publicly decried that Japan"s electoral assistance was abused by Cambodia"s Hun Sen government to consolidate its power in the 2018 general election. ${ }^{47}$ Although Japan"s assistance appears to have reinforced hierarchical governance structures in Myanmar, Cambodia, and other fragile and conflict-affected states, perhaps it would be erroneous to take this as the evidence of the Japanese "challenge" to the mainstream liberal peace paradigm. Scholars such as Visoka and Richmond note the supposedly "liberal" Western powers, including the European Union (EU) member-states, have also propped up illiberal and authoritarian regimes through postconflict interventions in Kosovo ${ }^{48}$ (and, perhaps, elsewhere - in Bosnia and Herzegovina, Moldova, Afghanistan, Iraq, Georgia, Egypt, Azerbaijan etc.). In this sense, Japan"s continuous support for hierarchical governance appears to be the rule rather than the exception, although its illiberal repercussions can be criticized on normative grounds.

On the positive side, Japan"s sovereignty-respecting approach has boosted its credibility as an impartial and non-intrusive peacebuilder. For instance, Japan emerged as a trusted partner in the Philippines where both Manila and the regional government in conflict-affected Mindanao willingly and actively participate in Japan-led peacebuilding programs such as the Japan-Bangsamoro Initiatives for Reconstruction and Development. $^{49}$

More broadly, historical processes and experiences discussed above have influenced Japan"s contemporary positioning with regard to its normative leadership - or, to be more precise, the lack thereof - in the field of peacebuilding (and beyond). For instance, the section on "human rights" first appeared in the Diplomatic Bluebook only in $1993,^{50}$ and Japan refrains from attaching strict political (democracy and human rights) conditionality to peacebuilding assistance and development aid. ${ }^{51}$ In 2014 , an American state-funded democracy promoter "Freedom House" published a policy report asserting that "Japan is a consolidated democracy with the world"s third-largest economy, but it has yet to undertake significant efforts to support democracy and human rights, even in Asia." 52 In peace operations, Tokyo has predominantly focused on the promotion of socio-economic development and refrained from actively asserting human rights agendas. Japan"s Grant Assistance for Grassroots Human Security Projects (which supports locally-driven civil society projects in developing countries and conflict-affected states), for example, explicitly prohibits financing "political" projects and instead prioritizes BHNs. ${ }^{53}$ 
As noted above, historical experiences play a crucial role in sustaining Japan"s passivity. In mainstream peacebuilding research, scholars often contrast normative, value-based "liberal" peacebuilding that vigorously promotes democracy and human rights, with pragmatic, "non-liberal" peacebuilding that emphasizes material interests. ${ }^{54}$ Here, the assertion of normative values is conceived as a "good" intervention, as opposed to a "bad" intervention that prioritizes national interests over universal values. However, for many Japanese policymakers, the aversion of normative foreign policy is informed by the critical lessons learned from the past. Prior to 1945, the Japanese Empire habitually branded itself as a visionary "Rising Sun" seeking to promote peace and "universal" humanistic ideals. At the 1919 Paris Peace Conference, for instance, Imperial Tokyo proudly proposed to include the Racial Equality Clause (Le principe de l'égalité des races) as an integral part of the peace accord. ${ }^{55}$ With the ambition to assume the role of a "non-white" norm maker in world affairs, ${ }^{56}$ the Japanese Empire proclaimed a moral responsibility to save and defend the "Great Asian Sphere of CoProsperity" from the encroachment of white supremacists. This logic of normative foreign policy was mobilized to justify Tokyo"s expansionist endeavors in the Asia-Pacific region, ostensibly for the sake of human liberation and emancipation.

After its defeat in 1945, Japanese leaders recognized that the assertion of excessive moral ambition is a strong impediment to peaceful international relations. It is in this sense that the lack of extrovert moral ambition came to entail a positive connotation, especially when it comes to sensitive issues of war and peace. Pragmatism is hence paradoxically reconstructed as a certain form of normativity, rooted in the spirit of mutual respect and pluralistic coexistence. Among the DAC donors, Japan has been the only state that explicitly proclaimed foreign aid as being provided to advance win-win cooperation based on national interests, mutual benefits, self-help, and self-reliance. ${ }^{57}$ This tendency has become even clearer under the Abe Administration that has promoted the concept of "Development Cooperation Serving National Interest". ${ }^{58}$ Here, the assertion of national interest in development cooperation is conceived as an honest foreign policy which transparently discloses real strategic motives, as opposed to deceptive foreign policy of the imperial era that disguised national interests in the clothes of "universal" values.

Of course, this is not to nihilistically contend that all assertions of universal values are equally deceptive. ${ }^{59}$ Yet mainstream Western scholarship tends to uncritically celebrate the assertion of normative absolutes, including the liberal peace, as a "good" practice, whereas the passivity in terms of value assertions is often conflated with a lack of principles. In the eyes of many Japanese policymakers, this dichotomy of a "good" value assertion versus "bad" value aversion does not make much sense. There is an alternative worldview rooted in Japan"s own historical experiences that contrasts the good, rational, realistic, honest, and pragmatic aversion of value imposition (e. g. postwar Japan) to the bad, emotional, idealistic, illusive, and self-aggrandizing assertion of normative absolutes (e.g. Imperial Japan). ${ }^{60}$ Where liberal peacebuilders see timid passivity in Japan"s peacebuilding assistance, many Japanese peacebuilders see enlightened modesty. Where liberal peacebuilders see Japan"s lack of principled insistence on democracy and human rights norms, many Japanese peacebuilders see the principled respect for sovereign autonomy. Finally, where liberal peacebuilders see Japan"s aversion to normative leadership, many Japanese peacebuilders see cautious gradualism and the absence of chauvinistic humanitarianism. 


\section{Conclusion}

A historically-grounded approach to the epistemological foundation of Japanese peacebuilding policy compels us to reconsider the taken-for-granted assumptions about the liberal peace. This article shows that, for historical reasons, the binary of the "liberal West" vs "non-liberal Rest" does not resonate well in Japan where the United States acted as an illiberal hegemonic power that promoted ostensibly liberal norms by autocratic means. In fact, there might be a regional consensus in Asia that the West stands for illiberal, conservative, and even dictatorial forces in conflict-affected societies in Asia. Indians often decry that the West has for long sided with "undemocratic" Pakistan against democratic India in South Asian conflicts. ${ }^{61}$ Like the Japanese liberals, the South Korean liberals complain that American hegemony is an obstacle to the reintegration and democratization of the Korean peninsula. ${ }^{62}$ In many ways, it was the West (and, above all, the United States) that consistently promoted illiberal developmental regimes in postconflict Asian nations. ${ }^{63}$ In the mainstream Western intellectual context, calling someone "illiberal" essentially constitutes a kind of insult. But it does not need to be. The United States earned lasting and wide-ranging respect from many postwar Japanese citizens because - and not despite - of the fact that it acted like a competent autocrat who effectively controlled information, imposed a strictly hierarchical order, tamed civil society, and thereby contained the seeds of postwar social disturbances and paved the way for Japan"s miraculous postwar growth. This paradoxical lived experience of postwar "liberalization" profoundly informs Japan"s contemporary peacebuilding practices. ${ }^{64}$

So far, the extant peacebuilding literature and its focus on the interplay between "global norms" and "local actors" neglects alternative approaches to peacebuilding, and indeed, often disparate strands within the liberal peacebuilding paradigm itself. The EU, for instance, seems to perceive itself as a champion of the liberal peace, but conflicts within itself remain unresolved and largely frozen (e. g., Cyprus and Northern Ireland). Although the EU promotes pluralistic postconflict societies where parochial divisions are liberally transcended, Belgium remains deeply divided between Flemish and French ethnic groups who cannot even agree to have a shared university. ${ }^{65}$ Likewise, American policymakers have advocated a pluralistic solution to polarized societies where opposing political parties (with different constituencies and normative visions) shall not see each other as an existential threat and shall seek a workable compromise and coexistence. But in the United States itself, many Republicans and Democrats now see each other as a moral danger. Beyond Japan, the much-needed debate on the role, vision, and agency of non-Western peacebuilders offers a promising avenue for future research.

\section{Endnotes}

\footnotetext{
${ }^{1}$ The binary of the "West"/"non-West" is obviously oversimplified and problematic, but the author uses the term as a heuristic to denote the mainstream Anglo-American/Western European worldviews. The author wants to thank Oliver Jütersonke for emphasizing this point. For more detailed conceptual reflections on this, see Vucetic 2011, Stuenkel 2011.

${ }^{2}$ Ministry of Foreign Affairs of Japan (MOFA) 2019.

${ }^{3}$ Yasutomo 1989.
} 
${ }^{4}$ The AGIPC was set up by the Cabinet Office in 2002 and headed by Yasushi Akashi, the former Head of the UN Transitional Authority in Cambodia and Under-Secretary-General for Humanitarian Affairs and Emergency Relief Coordinator (2001-2003).

${ }^{5}$ AGIPC 2002.

${ }^{6}$ See, e. g., Van der Lijn and Avezov 2015; Call and de Coning 2017.

${ }^{7}$ See Uesugi and Fujishige 2018; Asahi 2013.

${ }^{8}$ Ochiai 2019, Iwami 2016, Honda 2017. On the linkage between peacebuilding and development, see Krause and Jütersonke 2005.

${ }^{9}$ MOFA 2016, JICA 2009.

${ }^{10}$ Ruggie 1982. The author thanks Keith Krause for emphasizing this point.

${ }^{11}$ Shinoda 2009, p. 513.

12 JICA 2009, p. 16.

${ }^{13}$ For brevity"s sake, this article focuses on post-conflict governance issues and does not go into detail of Japan"s participation in peacekeeping operations. On the evolution of Japanese peacekeeping policy, see Ishizuka 2005, Hatakeyama 2011, Uesugi, Fujishige, Yoshizaki, and Honda 2016, Fujishige 2018.

${ }^{14}$ Tellidis 2012, p. 430.

${ }^{15}$ Kissinger 2014, p. 328.

${ }^{16}$ Hosoya 2018, p. 142.

${ }^{17}$ Shinoda 2009, p. 509.

${ }^{18}$ Lipset 1993, p. 151.

${ }^{19}$ Hosoya 2018, p. 224-225; see also Inoue 1991.

${ }^{20}$ Quoted in: Wall Street Journal 2016.

${ }^{21}$ Montgomery 1957.

${ }^{22}$ Snyder and Ballentine 1996.

${ }^{23}$ Yamamoto 1996.

${ }^{24}$ See Kishi 2018, Dower 1999.

${ }^{25}$ For an overview of the mainstream liberal postwar reforms, see Paris 2010.

${ }^{26}$ McElwain 2008, Scheiner 2005.

27 Johnson 1994.

${ }^{28}$ Fukuda-Parr and Shiga 2016, p. 18.

${ }^{29}$ Shinoda 2013, p. 77 (author"s own translation). On Japan"s developmental state order, see also Johnson 1994. 
${ }^{30}$ Interview with a Japanese peacebuilding scholar and peacebuilding program manager, Hiroshima, 17 February 2020.

${ }^{31}$ Sims 2000.

32 Inoue 2015.

${ }^{33}$ The 1998 NPO Act was instituted as a result of the 1995 Hanshin-Awaji Great Earthquake. After the earthquake, many volunteering and non-profit organizations were formed to engage in disaster relief and reconstruction programs. However, the lack of a legal basis for these organizations critically hindered the reconstruction efforts.

${ }^{34}$ The most prominent case was America"s direct interference in Japan"s judicial affairs. In 1955, local residents, student movements, and civil society activists organized mass protests against new U.S. plan to expand Tachikawa Airbase in Western Tokyo. In October 1956, the American-backed LDP regime mobilized armed riot police to crack down on street protesters, injuring over 1000 citizens. In 1957, the LDP regime persecuted seven students and activists for unlawful incursion into the U.S. military base, but civil society representatives insisted that the presence of American military forces in Japan was illegal and unconstitutional as it directly stood against the postwar constitutional norm of pacifism and the non-use of military force. In 1959, the Tokyo District Court ruled that the U.S. military presence in Japan was unconstitutional. For a brief moment, this was hailed as a victory of civic activism. However, immediately after the ruling, U.S. ambassador to Japan Douglas MacArthur II (the nephew of General MacArthur) organized a secret meeting with Chief Justice of the Japanese Supreme Court and insisted that the Supreme Court must unanimously overturn the district court ruling (Nikkei 2010) - which it soon did.

${ }^{35}$ Quoted in: Hosoya 2018, p. 51.

${ }^{36}$ On psychological trauma of foreign occupation in Japan, see Zarakol 2010.

${ }^{37}$ See Fukuda-Parr and Shiga 2016, p. 19.

38 JICA 2018, p. 3.

${ }^{39}$ See, e. g., Gilson 2007, Prantl and Nakano 2011.

${ }^{40}$ Hence, Asian nations that had been devastated by Japan"s despotic imperial policy received priority in aid allocation. China emerged as the largest recipient of Japanese postwar aid (Takamine 2005).

${ }^{41}$ Yasutomo 1989, lokibe 2003, Kondoh 2015, Shimomura, Page, and Kato 2016; Watanabe 2019.

42 JICA 2009.

${ }^{43}$ Interview with a senior JICA official, Tokyo, 28 January 2020; interview with a senior JICA official, Tokyo, 4 February 2020.

${ }^{44}$ Interview with a former senior UN official, Tokyo, 5 February 2020.

${ }^{45}$ Interview with a senior JICA official, Tokyo, 28 January 2020, interview with a senior JICA official, Tokyo, 4 February 2020.

${ }^{46}$ Watanabe 2019.

${ }^{47}$ Inoue 2018.

${ }^{48}$ Visoka and Richmond 2017.

${ }^{49}$ Ochiai 2019. 
${ }^{50}$ Ohnuma 1998, p. 281.

${ }^{51}$ Ichihara 2019

${ }^{52}$ Calingaert, Puddington, and Repucci 2014, p. 6.

${ }^{53}$ MOFA 2016.

${ }^{54}$ Höglund and Orjuela 2012, Smith 2014, Lewis, Heathershaw, and Megoran 2018.

${ }^{55}$ The proposal was bluntly rejected by President Woodrow Wilson who had been known for his support for white supremacist policies at home, such as re-segregation of governmental departments. Wilson"s personal rejection of the racial equality clause, among other white supremacist policies advanced under his administration, prompted a series of nationwide protest movements in 1919 that led to the death of over 100 African Americans (the so-called "Red Summer").

${ }^{56}$ Klotz 1995, p. 457.

${ }^{57}$ Kondoh 2015.

${ }^{58}$ See Ogawa 2019. Japan"s official development assistance (ODA) policy has evolved significantly under the Abe Administration, although a more thorough analysis on this theme goes beyond the scope of this article. The author thanks an anonymous reviewer for emphasizing this point.

${ }^{59}$ On the geopolitical dimension of norm assertion, see Hyde-Price 2006.

${ }^{60}$ This is somewhat similar to the state of affairs in sixteenth-century Europe, where the mainstream proclaimed a "value-based" European community bound by fundamental Christian values, as opposed to "valueless" secularism. From the viewpoint of secularists, however, the lack of emphasis on Christian values did not constitute total nihilism, but instead an alternative form of normativity rooted in rationalism and pragmatism (i.e. the aversion of inserting moral absolutes into politics).

${ }^{61}$ See, e. g., Stuenkel 2011.

${ }^{62}$ See, e. g., Oh and Arrington 2007.

${ }^{63}$ Stubbs 2018.

${ }^{64}$ See also Kobayashi 2018.

${ }^{65}$ Due to ethnic and linguistic divisions, Brussels has two versions of the Free University of Brussels: Dutch-speaking Vrije Universiteit Brussel (VUB) and French-speaking Université Libre de Bruxelles. In a similar vein, the Catholic University of Leuven split into Dutch-speaking Katholieke Universiteit Leuven and French-speaking Universite catholique de Louvain in the late 1960s and remains so until today. I thank Keith Krause for raising the example of the Catholic University of Leuven. In Kosovo, Bosnia and Herzegovina, and elsewhere in postconflict societies, the persistent division of ethnically and linguistically divided educational institutions are often considered as a failure of liberal peacebuilding, but the Belgian examples shows that pockets of conflict and fragility exist within liberal peacebuilders themselves. 


\section{BIBLIOGRAPHY}

1. Asahi H. Heiwakouchiku wo saikouchiku suru: Nihon no shiten kara no ichi kousatsu [Reconstructing Peacebuilding: A Japanese Reflection]. The Japan Institute of International Affairs (JIIA) Column. 21.08.2013. URL: https://www.jiia.or.jp/column/ column-229.html.

2. Biden gets Japan"s attention with nuclear remark // Wall Street Journal. 16.08.2016.

URL: https://www.wsj.com/articles/biden-gets-japans-attention-with-nuclear-remark1471424823.

3. Calingaert D., Puddington A., Repucci S. The Democracy Support Deficit: Despite Progress, Major Countries Fall Short. - Washington D.C.: Freedom House, 2014.

URL: https://freedomhouse.org/sites/default/files/2020-02/GSD_Overview_and_Country Reports.pdf.

4. Call C.T., De Coning C. Rising Powers and Peacebuilding: Breaking the Mold? Open Access eBook: Springer International. - Cham: Palgrave Macmillan, 2017.

DOI: 10.1007/978-3-319-60621-7.

5. Dower J.W. Embracing Defeat: Japan in the Wake of World War II. - New York: W.W.Norton \& Co. / The New Press, 1999.

6. Fujishige $\mathrm{H}$. Reisengo ni okeru jieitai no yakuwari to sono henyou: kihan no soukoku to shiyou, soshite "sekkyoku shugi" he no tenkai [The Role of JSDF after the Cold War and its Transformation: Norm Contestation, Norm Aufheben, and the Turn to "Robust" approach]. - Tokyo: Naigai Shuppan, 2018.

7. Fukuda-Parr S., Shiga H. Normative Framing of Development Cooperation: Japanese Bilateral Aid between the DAC and Southern Donors. Japan International Cooperation Agency (JICA) Research Institute Working Paper No. 130. 2016.

URL: https://www.jica.go.jp/jica-ri/publication/workingpaper/wp_130.html.

8. Gilson J. Building peace or following the leader? Japan"s peace consolidation diplomacy // Pacific Affairs. V. 80. No. 1. 2007. P. 27-47. DOI: 10.5509/200780127.

9. Hatakeyama K. Japan"s peacekeeping policy: Strategic calculation or internalization of an international norm? // Pacific Review. V. 27. No. 5. 2013. P. 629-650.

10. Heiwakouchiku shien: bunya wo meguru kokusaityouryuu [Peacebuilding Assistance: Current Trends]. Ministry of Foreign Affairs of Japan (MOFA). 29.06.2016.

URL: https://www.mofa.go.jp/mofaj/gaiko/oda/bunya/conflict/index.html.

11. Höglund K., Orjuela C. Hybrid peace governance and illiberal peacebuilding in Sri Lanka // Global Governance. V. 18. No. 1. 2012. P. 89-104. URL: www.jstor.org/stable/ 23104302.

12. Honda T. JICA no heiwakouchiku shien no rekishiteki tenkai, 1999-2015 [The historical development of JICA"s peacebuilding assistance policy, 1999-2015] // Kokusai Seiji. V. 186. 2017. P. 97-112.

13. Hosoya Y. Sengoshi no kaihou - Jishudokuritsu toha nanika Volume II: Part 1 - Haisen kara nihonkokukenpou seitei made [The Liberation of Postwar History - What Is Independence? V. II: Part 1. From the Defeat to the Birth of the Constitution]. - Tokyo: Shinchosha, 2018.

14. Hyde-Price A. "Normative" power Europe: a realist critique // Journal of European Public Policy. V. 13. No. 2. 2006. P. 217-234. DOI: 10.1080/13501760500451634.

15. Ichihara M. International Power Structure and Strategic Motivations: Democracy Support from Japan and Indonesia. JICA Research Institute Working Paper No. 194. 2019.

URL: https://www.jica.go.jp/jica-ri/publication/workingpaper/wp_194.html.

16. Inoue K. Nihon no ODA seisaku: Habahiroi jinzai atsumete kentou wo [Japan"s ODA policy should be reconsidered with the participation of broad-ranging experts] // Asahi Shinbun. 01.09.2018. URL: https://www.asahi.com/articles/DA3S13659507.html. 
17. Inoue K. MacArthur"s Japanese Constitution. - Chicago: University of Chicago Press, 1991.

18. Inoue T. Riberaru no koto ha kirai demo riberarisumu ha kirai ni naranaide kudasai [You may hate liberals but please do not nate liberalism]. - Tokyo: Mainichi Shinbun Shuppan, 2015.

19. lokibe M. ODA as a foreign policy tool // Japan Review of International Affairs. V.17. No. 2. 2003. P. 105-127.

20. Ishizuka K. Japan"s policy towards UN peacekeeping operations // International Peacekeeping. V.12. No.1. 2005. P. 67-86. DOI: 10.1080/1353331042000286568.

21. Iwami T. Understanding Japan"s peacebuilding in concept and practice // East Asia. V. 33. No. 2. 2016. P. 111-132. DOI: 10.1007/s12140-016-9255-9.

22. Johnson Ch. Japan: Who Governs? Rise of the Developmental State. - New York: Norton, 1995.

23. Kadaibetsu houshin: heiwakouchiku [Thematic Guideline: Peacebuilding]. JICA, September 2009. URL: https://www.jica.go.jp/ activities/issues/peace/index.html.

24. Kishi K. Sengo zero nen: Tokyo black hole [The Postwar Year Zero: Tokyo Black Hole]. - Tokyo: NHK Press, 2018.

25. Kissinger $\mathrm{H}$. World order. - London: Penguin Books, 2014.

26. Klotz A. Norms reconstituting interests: global racial equality and US sanctions against South Africa // International Organization V. 49. No. 3. 1995. P. 451-478.

DOI: $10.1017 /$ S0020818300033348.

27. Kobayashi K. Keep Calm and Carry On? A Japanese Perspective on a Post-Liberal World. Russian International Affairs Council (RIAC) Analytics. 14.09.2018.

URL: https://russiancouncil.ru/en/analytics-and-comments/analytics/keep-calm-and-carry -on-a-japanese-perspective-on-a-post-liberal-world.

28. Kokusaiheiwakyouryoku kondannkai houkokusho [Report of the Advisory Group on International Peace Cooperation (AGIPC)]. 18.12.2002. URL: https://www.kantei.go.jp/ jp/singi/kokusai/kettei/021218houkoku.html.

29. Kondoh $\mathrm{H}$. Convergence of Aid Models in Emerging Donors? Learning Processes, Norms and Identities, and Recipients. JICA Research Institute Working Paper No. 106. 2015. URL: https://www.jica.go.jp/jica-ri/publication/workingpaper/post_16.html.

30. Krause K., Jütersonke O. Peace, security and development in post-conflict environments // Security Dialogue. V. 36. No. 4. 2005. P. 447-462. DOI: 10.1177/0967010605060449.

31. Lewis D., Heathershaw J., Megoran N. Illiberal peace? Authoritarian modes of conflict management // Cooperation and Conflict. V. 53. No. 4. 2018. P. 486-506.

DOI: $10.1177 / 0010836718765902$.

32. Lipset S. M. Pacific divide: American exceptionalism - Japanese uniqueness // International Journal of Public Opinion Research. V. 5. No. 2. 1993. P. 121-166.

DOI: 10.1093/ijpor/5.2.121.

33. McElwain K. M. Manipulating electoral rules to manufacture single-party dominance // American Journal of Political Science. V. 52. No. 1. 2008. P. 32-47.

DOI: 10.1163/9789004380523_018.

34. Montgomery J. D. Forced to be Free: The Artificial Revolution in Germany and Japan. Chicago: University of Chicago Press, 1957.

35. NGO daihyou afugan hukkoukaigi ni sanka dekizu: gaimushou ni hihan [A NGO representative who had criticized the Foreign Ministry was denied to take part in the Afghan reconstruction conference] // Asahi Shinbun. 21.01.2002.

URL: http://www.asahi.com/national/update/0121/005.html.

36. Ochiai N. Firipinn Mindanao: heiwa to kaihatsu [Philippine"s Mindanao: Peace and Development]. - Tokyo: Saiki Shuppan, 2019. 
37. ODA Statistics by OECD. MOFA Press Release. 11.04.2019. URL: https://www.mofa.go. jp/mofaj/press/release/press4_007306.html.

38. Ogawa Y. Normality of international norms power, interests, and knowledge in Japan"s ODA politics // Journal of International Development Studies. V. 28. No. 3. 2020. P. 5-18. DOI: $10.32204 /$ jids.28.3 5.

39. Oh Ch. H., Arrington C. Democratization and changing anti-American sentiments in South Korea // Asian Survey. V. 47. No. 2. 2007. P. 327-350.

DOI: 10.1525/as.2007.47.2.327.

40. Paris R. Saving liberal peacebuilding // Review of International Studies. V. 36. No. 2. 2010. P. 337-365. DOI: 10.1017/S0260210510000057.

41. Prantl J., Nakano R. Global norm diffusion in East Asia: how China and Japan implement the responsibility to protect // International Relations. V. 25. No. 2. 2011. P. 204-223. DOI: 10.1177/0047117811404450.

42. Ruggie J. G. International regimes, transactions, and change: embedded liberalism in the postwar economic order // International Organization. V. 36. No. 2. 1982. P. 379-415. DOI: $10.1017 / S 0020818300018993$.

43. Scheiner E. Democracy Without Competition in Japan: Opposition Failure in a One-Party Dominant State. - Cambridge: Cambridge University Press, 2005.

44. Sekai wo kaeru nihonshiki "houdukuri" [Japanese-style Legal Assistance That Changes the World]. JICA report. - Tokyo: Bungei Shunju, 2018.

45. Japan"s Development Assistance Foreign Aid and the Post-2015 Agenda. Ed. by Y.Shimomura, J.Page and H.Kato. - London: Palgrave Macmillan, 2016.

46. Shinoda H. Heiwakouchiku nyuumon [Introduction to Peacebuilding]. - Tokyo: Chikumashobo, 2013.

47. Shinoda H. Heiwakouchiku purosesu to shiteno nihon no kindaika to sengohukkou: naiteki heiwa to gaiteki heiwa [Japan"s Modernization and Postwar Reconstruction as a Peacebuilding Process: Internal and External Peace]. IPSHU Kenkyuhokoku Series. V. 42. 2009. P. 494-524.

48. Sims C. Three dead marines and a secret of wartime Okinawa // New York Times. 01.06.2000.

49. Smith C. Q. Illiberal peace-building in hybrid political orders: managing violence during Indonesia"s contested political transition // Third World Quarterly. V. 35. No. 8. 2014. P. 1509-1528. DOI: 10.1080/01436597.2014.946277.

50. Snyder J., Ballentine K. Nationalism and the marketplace of ideas // International Security. V. 21. No. 2. 1996. P. 5-40. DOI: 10.2307/2539069.

51. Spreading Smiles throughout the World: Grant Assistance for Grass-roots Human Security Projects. MOFA. 2016. URL: https://www.mofa.go.jp/mofaj/gaiko/oda/files/ 000071826.pdf.

52. Stubbs R. Order and contestation in the Asia-Pacific region: liberal vs developmental/non-interventionist approaches // The International Spectator. V. 53. No. 1. 2018. P. 138-151. DOI: 10.1080/03932729.2018.1402581.

53. Stuenkel O. Identity and the concept of the West: the case of Brazil and India // Revista Brasileira de Política Internacional. V. 54. No. 1. 2011. P. 178-195.

DOI: 10.1590/S0034-73292011000100011.

54. "Sunagawa jiken" no kaidan bunsho, gaimushou "sonzai shinai", iten kaiji [The Foreign Ministry used to insist that internal records with regard to "Sunagawa case" secret meetings did not exist, but they are now revealed] // Nikkei. 03.04.2020.

URL: https://www.nikkei.com/article/DGXNASDG0301E_T00C10A4CR8000/.

55. Takamine T. A new dynamism in Sino-Japanese security relations: Japan"s strategic use of foreign aid // The Pacific Review. V. 18. No. 4. 2005. P. 439-461.

DOI: $10.1080 / 09512740500338861$. 
56. Tellidis I. The end of the liberal peace? Post-liberal peace vs. post-liberal states // International Studies Review. V. 14. No. 3. 2012. P. 429-435. DOI: 10.1111/j.14682486.2012.01137.x.

57. Uesugi Y., Fujishige H. Kokusai heiwakyouryoku nyuumon [Introduction to International Peace Cooperation]. - Tokyo: Minerva Shobo, 2018.

58. Uesugi Y., Fujishige H., Yoshizaki T., Honda T. Sekaini muketa all Japan: heiwakouchiku, jindoushien, saigaikyuuen no atarashii katachi [The All-Japan Approach towards the World Peace: New Forms of Peacebuilding, Humanitarian Assistance, and Disaster Relief]. - Tokyo: Naigai Shuppann, 2016.

59. Van der Lijn J., Avezov X. The Future Peace Operations Landscape: Voices from Stakeholders around the Globe. - Stockholm: Stockholm International Peace Research Institute (SIPRI), 2015. URL: https://www.sipri.org/publications/2015/future-peaceoperations-landscape-voices-stakeholders-around-globe.

60. Visoka G., Richmond O. After liberal peace? From failed state-building to an emancipatory peace in Kosovo // International Studies Perspectives. V. 18. No. 1. 2017. P. 110-129. DOI: 10.1093/isp/ekw006.

61. Vucetic S. The Anglosphere. - Stanford: Stanford University Press, 2011.

62. Watanabe M. Henkasuru kankyou to nihon no enjoseisaku: futatsu no seihukaihatsuenjo taikou no sakutei kara [Japan"s Aid Policy in a Changing World: A Review of the Two Development Aid Charters]. Background Papers on the History of Japan"s Development Cooperation No. 4. URL: https://www.jica.go.jp/jica-ri/ja/publication/other/20180925_01. html.

63. Yamamoto T. Senryouki media bunseki [The Analysis of Media in the Occupation Period]. - Tokyo: Housei University Press, 1996.

64. Yasutomo D. T. Why aid? Japan as an "aid great power" // Pacific Affairs. V. 62. No. 4. 1989. P. 490-503. DOI: $10.2307 / 2759672$.

65. Zarakol A. After Defeat: How the East Learned to Live with the West. - Cambridge: Cambridge University Press, 2010. 